\author{
Harun Reşit CEYLAN ${ }^{1}$, Hakan ÇifTÇi ${ }^{1 *}$, Mustafa GÜRSOY ${ }^{1}$, Zeyni ARSOY ${ }^{1}$, Atilla EVCiN² ${ }^{2}$ Bahri \\ ERSOY ${ }^{1}$ \\ ${ }^{1}$ Afyon Kocatepe Üniversitesi, Mühendislik Fakültesi, Maden Mühendisliği Bölümü, Afyonkarahisar. \\ ${ }^{2}$ Afyon Kocatepe Üniversitesi, Mühendislik Fakültesi, Malzeme Bilimi ve Mühendisliği Bölümü, Afyonkarahisar.
}

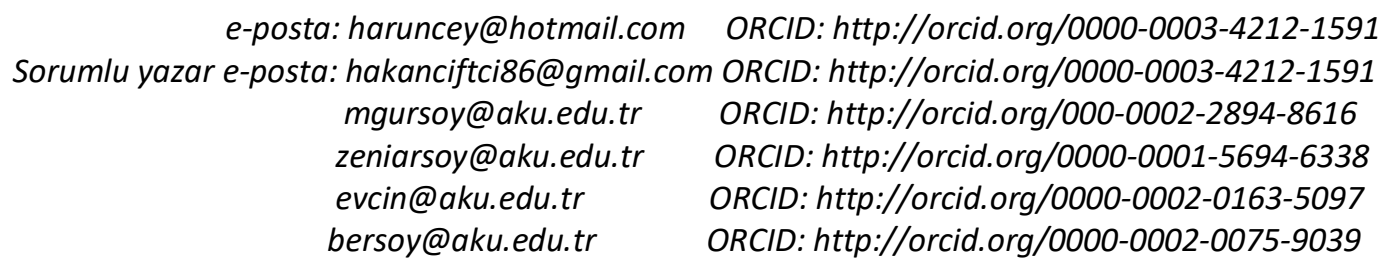

Geliş Tarihi: 05.11.2019 Kabul Tarihi: 24.03.2020

\begin{tabular}{|c|c|}
\hline & bst \\
\hline & $\begin{array}{l}\text { In this study, the effects of certain cleaning chemicals on the surface properties of a specific marble } \\
\text { sample (Bilecik beige) were investigated as a function of chemical type, chemical concentration, and }\end{array}$ \\
\hline Marble; Cleaning & contact time. Descaler, diluted $\mathrm{HCl}$ (spirits of salt), soft soap, surface cleaner, bleach, diluted nitric acid, \\
\hline Chemicals; Surface & liquid scouring cream, dish soap, grease cleaner and synthetic thinner were used in the tests as cleaning \\
\hline Roughness; Surface & chemicals. It was observed that the contact of highly acidic chemicals (nitric acid, salt of sipits, and \\
\hline Glossiness; Surface & descaler) on the marble surfaces for $840 \mathrm{~h}$ increased the surface roughness to unmeasurable point. In \\
\hline Color & addition, surface glossiness of the marble was completely disappeared, loss in mass of marble was \\
\hline & $\begin{array}{l}\text { more than } 1 \% \text {, and surface color was changed. Neutral and alkaline chemicals, however, changed } \\
\text { marble surface properties slightly compared to acidic chemicals. }\end{array}$ \\
\hline
\end{tabular}

\title{
Çeşitli Temizlik Kimyasallarının Mermerlerin Yüzey Özelliklerine Etkisi
}

\begin{abstract}
Öz
Bu çalışmada, bazı temizlik kimyasallarının belirli bir mermer numunesinin (Bilecik Bej) yüzey özellikleri

Anahtar kelimeler

Mermer; Temizlik

Kimyasalları; Yüzey

Pürüzlülüğü; Yüzey

Parlaklığı; Yüzey Rengi üzerindeki etkileri, kimyasal çeşidi, kimyasal derişimi ve temas süresinin bir fonksiyonu olarak incelendi. Kireç çözücü, seyreltilmiş $\mathrm{HCl}$ (tuz ruhu), arap sabunu, yüzey temizleyici, çamaşır suyu, seyreltilmiş nitrik asit, sıvı temizleme kremi, bulaşık deterjanı, yağ temizleyici ve sentetik tiner testlerde temizlik kimyasalları olarak kullanıldı. Yüksek derecede asidik kimyasalların (nitrik asit, tuz ruhu ve kireç çözücü) 840 saat boyunca teması mermer yüzeyi üzerinde ölçülemez derecede yüzey pürüzlülüğüne sebep oldu. Bununla birlikte, mermerin yüzey parlaklığı tamamen ortadan kalktı, mermer kütlesindeki kayıp \%1'in üzerine çıktı ve yüzey renginin değiştiği tespit edildi. Nötr ve bazik kimyasalların ise mermer yüzey özelliklerini asidik kimyasallara göre çok az seviyede değiştirdiği tespit edildi.
\end{abstract}

(C) Afyon Kocatepe Üniversitesi

\section{Introduction}

Consuming of robust, malleable and easily cleanable natural stones such as granite and marble is increasing day by day. It is desirable that natural stones used for decorative purposes should be long-lived and not lose their aesthetic appearance. However, it is also known that the physical and chemical characteristics of natural stones change in time under various environmental conditions such as water, humidity, hot and cold weather. Surface aging, discoloration, tarnishing, spalling, mass loss, mechanical strength reduction, and formation of fractures can be observed on the natural stone structures as a result of these environmental effects. Additionally, large amounts 
of various chemicals are used for the surface cleaning and therefore the surface properties of the natural stones change over time. When the studies on natural stone surfaces in literature were examined, it was determined that most of the studies were on the decomposition of natural stones caused by atmospheric conditions (Gökaltun 2005; Tecer and Cerit 2001; Spiker et al. 1995; Schuster et al. 1994). Gökaltun 2005, exposed natural stone samples to atmospheric effects (rain, snow) for a certain period of time and measured the glossiness changes of the samples. It was reported that the glossiness losses of the marble and travertine samples was higher than granite samples. Spiker et al. 1995, carried out some experiments by changing the environmental effects such as wind speed, humidity and temperature in the laboratory in order to determine the amount of $\mathrm{SO}_{2}$ deposited on limestone and marble surfaces as a result of acid rain. Vella et al. 1996, investigated the reasons for the deterioration of limestones covered on the outer walls of churches in Malta. As a result of the research, they determined that the cause of the deterioration in limestones was caused by sulfur dioxides from thermal power plants. Moropoulou et al. 2006, performed SEM EDX image analyzes to investigate the decomposition of natural stones by atmospheric effects. As a result it is reported that $\mathrm{SO}_{2}$ accumulation causes cracks in natural stones.

Few studies were performed to investigate the effects of various cleaning chemicals on the natural stone surfaces. Some of studies were summarized as follows. In a study carried out by Gündüz vd. 1996, several marble samples obtained from different regions were subjected to sodium sulfate decahydrate solution as a function of contact time. As a result, mass loss of the marble sample was reported as 1-5\%. Gökaltun 2004, kept some chemicals on the surface of natural stones for 5 min and observed the loss of surface glossiness. The loss of glossiness of the marble sample reached high rates while it remained limited in granites after the contact of the spirits of salt and the descaler on the surface of samples. The surface cleaner chemical was observed to have more effect on the granite surface glossiness than the spirits of salt and descaler. The effect of the bleach on the glossiness of the natural stones was considerably less than that of acidic chemicals.

There are many chemicals used to clean natural stones and should be examined in detail for their effect on the surface of natural stones, especially as a function of contact time. In this study, it is aimed to investigate the effects of various cleaning chemicals on the polished marble surface in detail. The experiments were carried out with 10 different cleaning chemicals (acidic, alkaline, and neutral) prepared in 3 concentrations. The changes in the surface properties (surface glossiness, roughness, color, and mass) of the marble were observed as a function of contact time and chemical concentration.

\section{Materials and Methods}

\subsection{Materials}

Polished Bilecik beige marble samples $(10 \times 10 \times 2$ $\mathrm{cm})$ were supplied from Merdivenci Marble Company located in Afyonkarahisar-Turkey. Chemical cleaners (descaler, spirits of salt, soft soap, surface cleaner, bleach, diluted nitric acid, liquid scouring cream, dish soap, grease cleaner, and thinner) used in this study were obtained from Eskişehir Detsan Kimya Co. Some characteristics of chemicals used are given in Table 1.

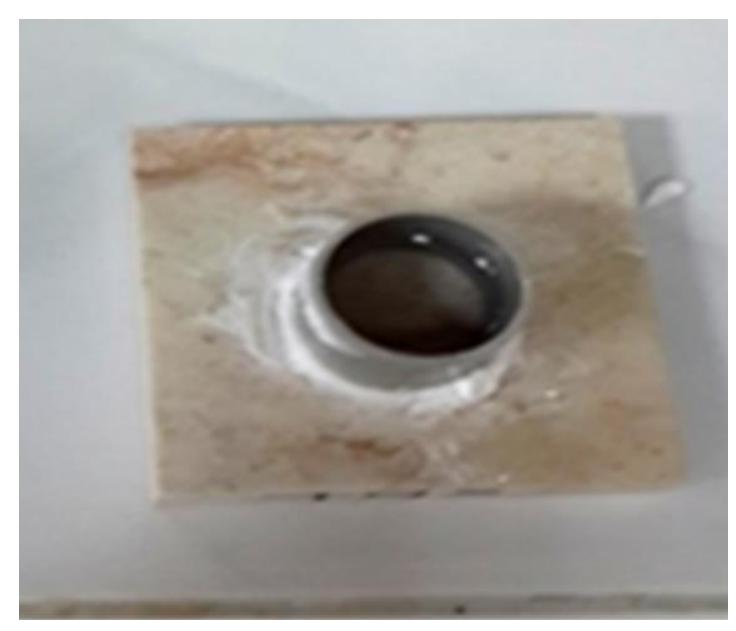

Figure 1. Plastic pipe on the marble surface.

\subsection{Characterization Studies}


Mineralogical analysis of the marble sample was carried out on a Shimadzu XRD-6000 instrument with $\mathrm{Cu}-\mathrm{K} \alpha$ radiation $(\lambda: 1,54184 \AA$ ) $)$ at $40 \mathrm{kV}$. The sample was scanned in the angular range of $2-70^{\circ}$ with a scan rate of $0,02^{\circ} /$ step. Chemical analysis was performed on RIGAKU/ZSX Primus II X-ray fluorescence (XRF) instrument to determine elementel composition of the sample quantitatively. Micromeritics AutoPore IV 9500 mercury-porosimetry device was used to determine the porosity structure of samples. Surface roughness of the marbles was measured by TIME TR 200 device after the polished marble samples were cleaned with a damp cloth. Surface roughness is expressed by relatively small intermittent surface irregularities resulting from the production methods used (TS 6956/2004). The colors of the marble samples were obtained from a Hunterlab color analyzer after cleaning and drying of the samples for $24 \mathrm{~h}$ at $100^{\circ} \mathrm{C}$. Glossiness measurements were performed at the midpoint of the polished surface of the samples at a $60 \mathrm{o}$ angle using a Novo Gloss Trio digital glossiness meter. 10 samples were used for each surface analysis, 4 measurements were taken from each sample, and the average of the results obtained was recorded.

Table 1. Ingredients and $\mathrm{pH}$ values of cleaning chemicals used.

\begin{tabular}{llc}
\hline Cleaning Chemicals & Ingredient & pH \\
\hline Descaler & $\mathrm{HNO}_{3} 20 \%, 2-6 \% \mathrm{H}_{3} \mathrm{PO}_{3}$ & 0,5 \\
Spirits of salt & $\mathrm{HCl}, 20 \%$ & 0,5 \\
Nitric acid & $\mathrm{HNO}_{3}, 56 \%$ & 0,5 \\
Synthetic Thinner & $\mathrm{HC}$ with aliphatic and aromatic & 6,00 \\
Surface cleaner & Anionic substance <5\%, Nonionic substance <5\%, methylisothiazolinone & 7,00 \\
Dish soap & Alkyl benzene sulfonic acid, sodium salt 5-10\% ethoxylated, sulfates 1-5\% & 7,00 \\
Liquid scouring cream & Anionic surface active agent<5\%, nonionic surface active agent & 11,00 \\
& $<5 \%$ benzinsothiazolinone & 11,00 \\
Bleach & Sodium hypochlorite <4,5\%, Sodium hydrochloride <5\% & 13,00 \\
Grease cleaner & nonionic surface active agent <5\%, Sodium hydrochloride 1-3\% & 9,00 \\
Soft Soap & $20-25 \%$ Oil acid <5\% Alkaline substance & \\
\hline
\end{tabular}

\subsection{Application of Cleaning Chemicals}

First, a plastic pipe with $3 \mathrm{~cm}$ diameter and $3 \mathrm{~cm}$ height was placed in the middle parts of the marble samples $(10 \times 10 \times 2 \mathrm{~cm})$ as shown in the Figure 1 . The part of the plastic pipe contacting the marble surface was sealed with silicone on the outside to ensure impermeability. Approximately $14 \mathrm{~cm}^{3}$ cleaning chemical was then added into the plastic pipe mounted on the marble sample. The pipe and chemical removed from the marble surface at the end of determined contact time. Finally, the surface of marble was cleaned with distilled water, dried at $80^{\circ} \mathrm{C}$ for $4 \mathrm{~h}$, and then analyzed to determine the change of the sample characteristics. The effects of the cleaning chemicals on the marble surfaces were investigated separately depending on chemical concentration (original base $100 \%$, diluted with water 50\%, and 25\%), contact time, and chemical type (Table 2). Contact time and chemical concentrations were kept constant as $840 \mathrm{~h}$ (total 5 years of exposure for $30 \mathrm{~min}$ per day) and $100 \%$ (original base), respectively, in the experiments depending on the chemical type.

Table 2. Investigated parameters and value ranges.

\begin{tabular}{ccc}
\hline $\begin{array}{c}\text { Chemical } \\
\text { type }\end{array}$ & $\begin{array}{c}\text { Chemical } \\
\text { concentration (\%) }\end{array}$ & $\begin{array}{c}\text { Contact time } \\
\text { (h) }\end{array}$ \\
\hline Descaler, Spirits & 25 & 0,5 \\
of salt, Nitric & 50 & 3,5 \\
acid, Thinner, & 100 & 14 \\
Surface cleaner, & & 42 \\
Dish soap, & & 84 \\
Liquid scouring & & 168 \\
cream, Bleach, & & 840 \\
Grease cleaner, & & \\
Soft Soap & &
\end{tabular}




\section{Results}

\subsection{Characterization of Marble Sample}

Micrographs of Bilecik beige marble (Figure 2) revealed that the sample composed of calcite crystals having size range of $0,9-42,6 \mu \mathrm{m}$.
Significant numbers of micro cracks inside of texture and the crack openings were between 13,0$122,9 \mu \mathrm{m}$. The openings were filled by subhedral calcite crystals. It was confirmed that the oolithic existence was present in the rock and the oolithic forms had grain size range of $57,0-508,9 \mu \mathrm{m}$.
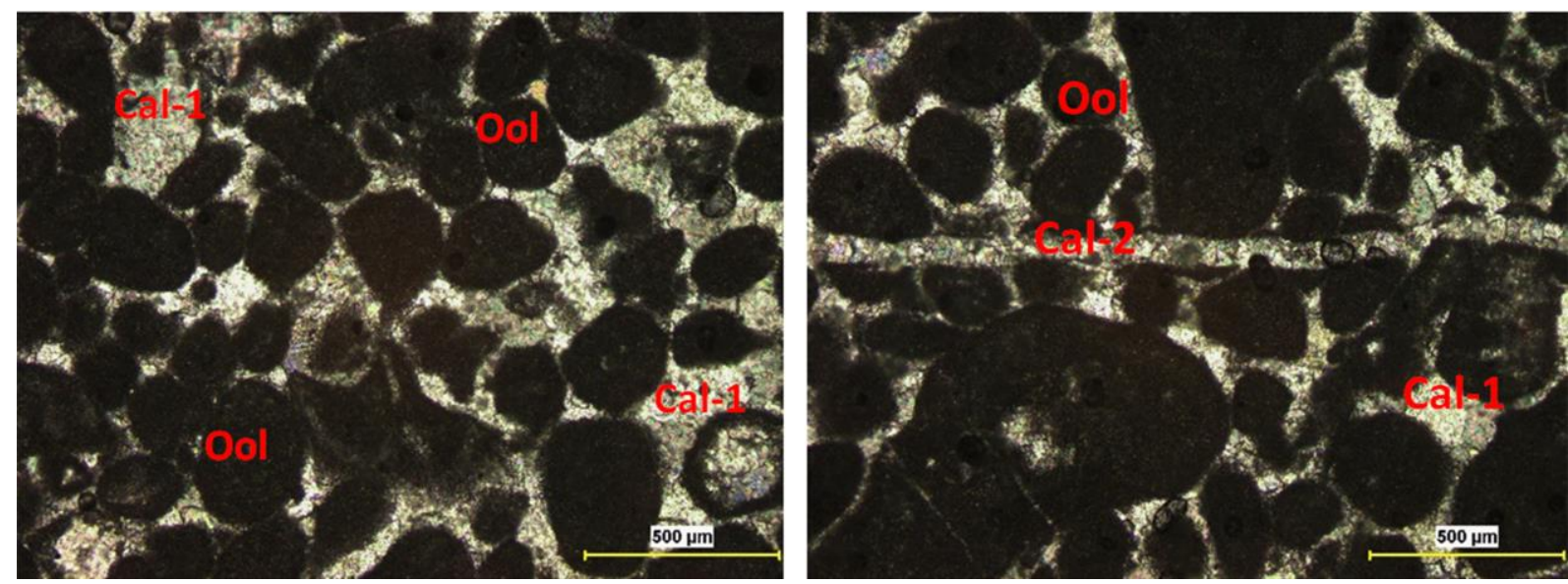

Figure 2. Primary (cal-1) and secondary (cal-2) calcite minerals which monitored inside of the rock and Double-nicol polarizing microscope images of Oolitic (Ool) particles seen as round shape.

Mineralogical/petrographic test results of Bilecik beige marble samples (Table 2 ) revealed that the sample is a sedimentary rock of calcite origin and the presence of secondary calcite structures in cracks was ascertained. The average grain size of the calcite minerals was determined as 6,32 $\mu \mathrm{m}$ while secondary calcites average grain size was determined to be $25,8 \mu \mathrm{m}$.

Table 2. Mineralogy/petrography results of Bilecik beige marble.

\begin{tabular}{lccc}
\hline \multirow{2}{*}{ Mineral } & \multicolumn{3}{c}{ Grain size $(\boldsymbol{\mu m})$} \\
\cline { 2 - 4 } & Minimum & Maximum & Average \\
\hline Calcite & 0,9 & 42,6 & 6,32 \\
Secondary & 6,7 & 72,3 & 25,8 \\
calcite & 57,0 & 508,9 & 229,9 \\
Oolite & 13,0 & 122,9 & 48,3 \\
Crack width & & & \\
\hline
\end{tabular}

According to the analysis performed by mercuryporosimetry device, the total pore volume of the marble sample was $0,002 \mathrm{~mL} / \mathrm{g}$, the total pore surface area was $0,122 \mathrm{~m}^{2} / \mathrm{g}$, the average pore diameter was $64,8 \mathrm{~nm}$, and the visible density was measured as $2,2453 \mathrm{~g} / \mathrm{cm}^{3}$.
Average surface roughness of the samples was measured as 0,174 $\mu \mathrm{m}$. Average surface whiteness value were measured as 72,31 (surface redness: 4,82, surface whiteness: 12,17), and average surface glossiness was measured as 69,4 gloss. XRF analysis results (Table 3 ) revealed that the sample composed of a high proportion of $\mathrm{CaO}$ with a percentage of $55,42 \%$. Therefore it was concluded that the sample contains high degree $\mathrm{CaCO}_{3}$ (calcite) mineral and named as crystallized limestone.

Table 3. Chemical analysis result of Bilecik beige marble.

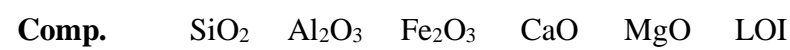

$\begin{array}{lllllll}\begin{array}{l}\text { Quantity } \\ \text { (wt.\%) }\end{array} & 0,4 & 0,16 & 0,08 & 55,4 & 0,3 & 43,5\end{array}$

LOI: Loss on ignition.

XRD pattern of the marble sample given in Figure 3 showed that the samples were mainly constituted by calcite and traces of quartz minerals. Similar results were obtained by other studies (Park et al. 2014). 


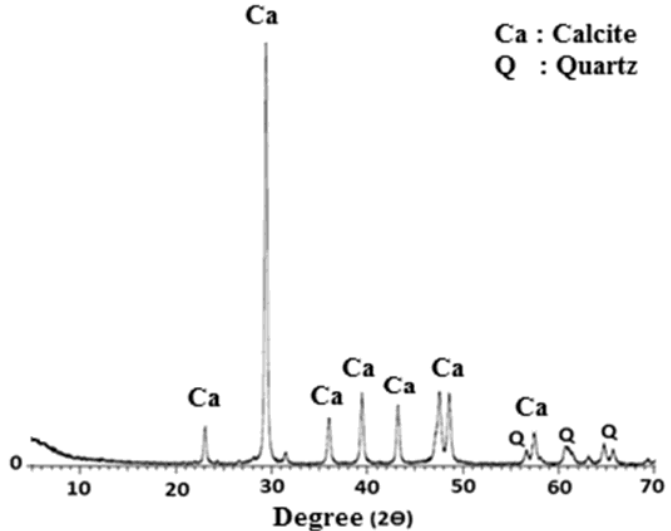

Figure 3. XRD pattern of the Bilecik beige marble.

\subsection{Effects of Cleaning Chemicals on the Marble Surface}

\subsubsection{The change of roughness}

The changes observed in surface roughness of the samples are given in Figure 4. Alkaline, low acidic and neutral chemicals did not have much effect on roughness while grease cleaner, thinner, liquid scouring cream and bleach caused averagely 0,004 $\mu \mathrm{m}$ increase in roughness. Emergence of $\mathrm{CO}_{2}$ gas and water during the reaction between calcite minerals and $\mathrm{HCl} / \mathrm{HNO}_{3}$ acids (Equation 1-2) resulted in cavities on the sample surfaces at a depth of $0,2 \mathrm{~mm}-10 \mathrm{~mm}$. Since high degree of roughness $(>0,5 \mathrm{~mm})$ occurred in the opened cavities (Figure 4), roughness measurements could not be performed on the marble surfaces where acidic chemicals were applied.

$\mathrm{CaCO}_{3}+\mathrm{HCl} \rightarrow \mathrm{H}_{2} \mathrm{O}(\mathrm{l})+\mathrm{CO}_{2}(\mathrm{~g})+\mathrm{CaCl}_{2}$

$$
\mathrm{CaCO}_{3}+2 \mathrm{HNO}_{3} \rightarrow \mathrm{Ca}\left(\mathrm{NO}_{3}\right)_{2}+\mathrm{CO}_{2}+\mathrm{H}_{2} \mathrm{O}
$$

Surface roughness increased linearly as concentration of cleaning chemicals and contact time increased. While acidic chemicals caused roughness on the marble surface that is not measurable, alkaline cleaners caused a slight roughness in the range of $0,001-0,004 \mu \mathrm{m}$. The roughness is the result of dissolution of calcite minerals in high range when contact with acidic chemicals (Equation 1-2). In contrast to this situation, dish soap and surface cleaner which having neutral $\mathrm{pH}$ levels did not cause significant abrasion on the marble surfaces.
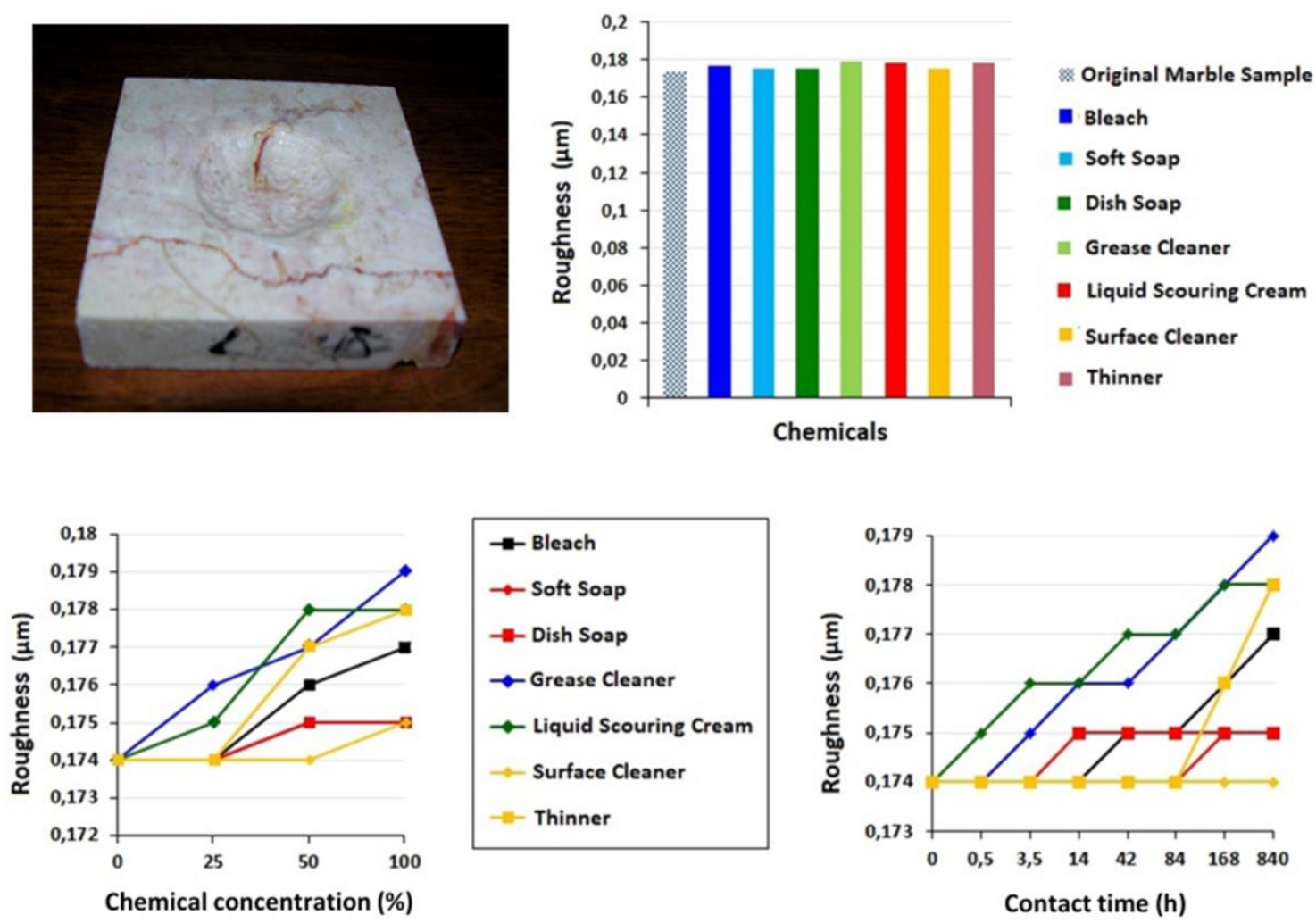

Figure 4. Effects of surface cleaning chemicals on the roughness of the marble surface. 


\subsubsection{The change of mass}

The changes in the mass of the marble samples after the contact of cleaning chemicals are given in Figure 5. Acidic chemicals such as nitric acid, descaler, and spirits of salt chemicals were the leading chemicals causing highest mass losses. This can be explained by the highest abrasion as a result of reaction of calcite minerals with acids (Equation 1-2). Mass loss rates increased when the chemical concentration and contact time increased. At the end of $840 \mathrm{~h}$ contact time, the mass losses in marble samples according to $25-50-100 \%$ concentrations were determined to be $1-2,2-4,0 \%$ for nitric acid, $0,7-1,2-2,0 \%$ for spirits of salt, and $0,3-0,7-1,2 \%$ for descaler, respectively. In the application of the remaining surface cleaning chemicals (alkaline and neutral), micro-level roughness was observed in the samples but no significant loss of mass was observed.
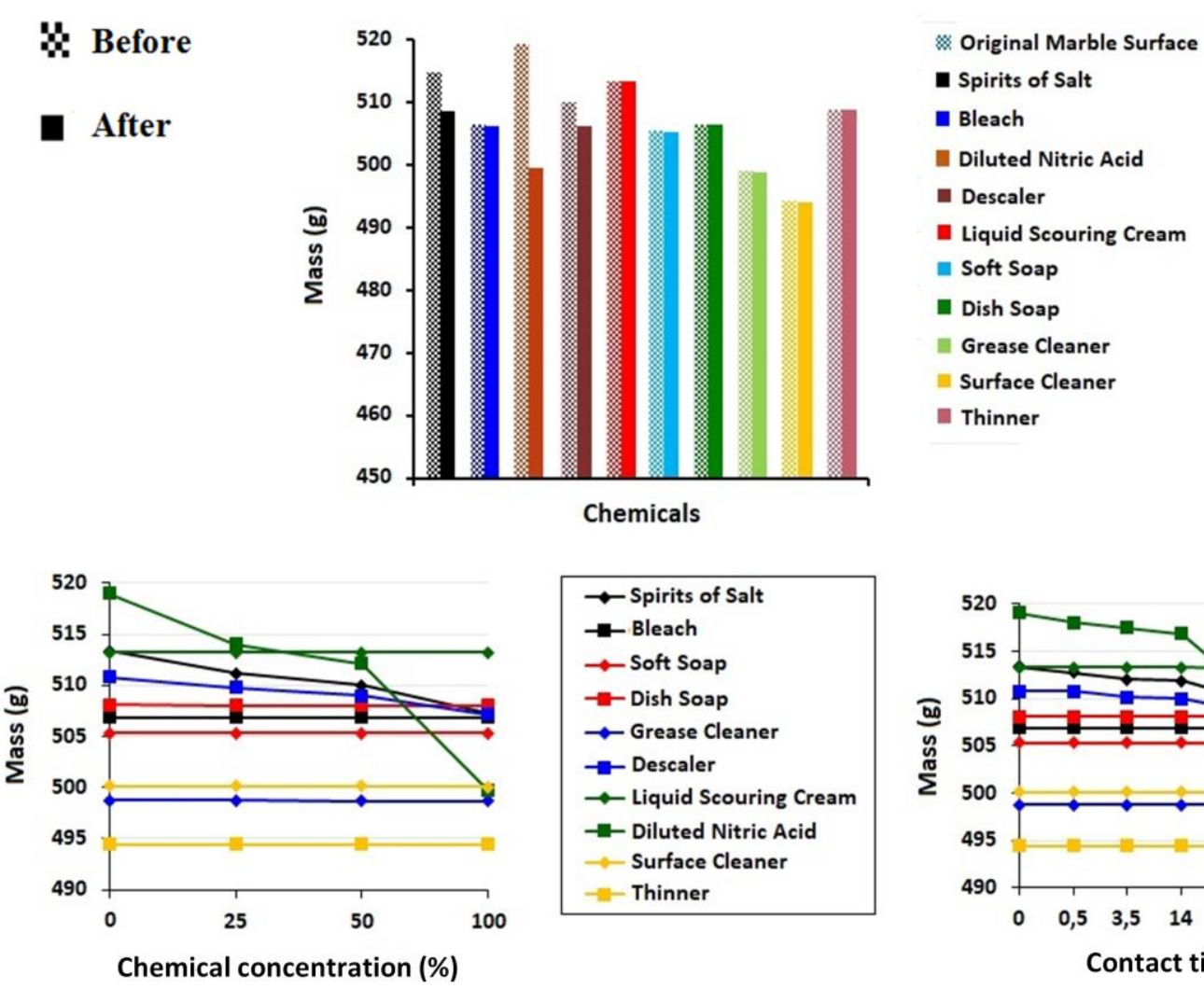

Chemicals
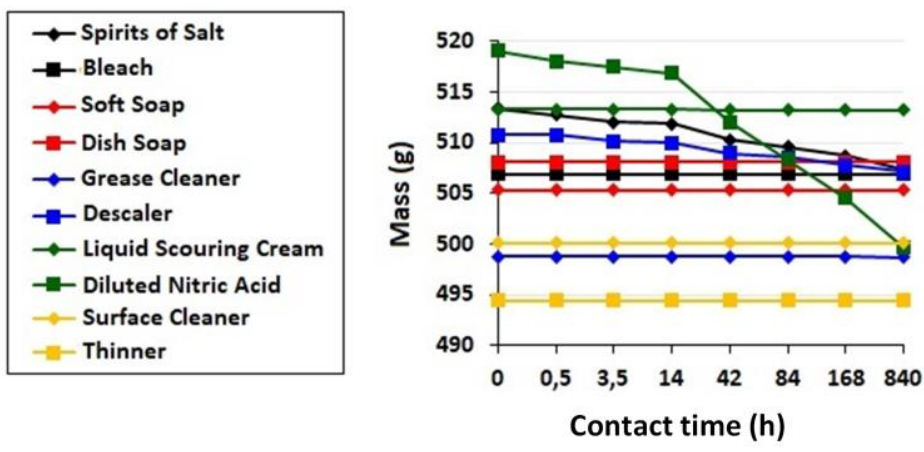

Figure 5. Effects of surface cleaner chemicals on the marble mass.

\subsubsection{The change of glossiness}

The surfaces of the marbles are polished with acidic solid materials. Polishing is based on the principle of reducing the micro-roughness on the surface of the marble by reaction of acid and calcite minerals. In particular, acidic chemicals cause corrosion at high concentrations and/or prolonged contact, while the roughness at the micron levels leads to loss of glossiness. Effects of cleaning chemicals on the glossiness of marble surfaces according to contact time, chemical type, and chemical concentration are given in Figure 6. Surface glossiness loss was mostly caused by nitric acid, spirits of salt, and descaler, respectively. Since these chemicals are strongly acidic, they chemically react with the calcite minerals in the sample and abrade the surface. As the concentration containing strong acids increased, the dissolutionetching effect of marble surfaces also increased. 

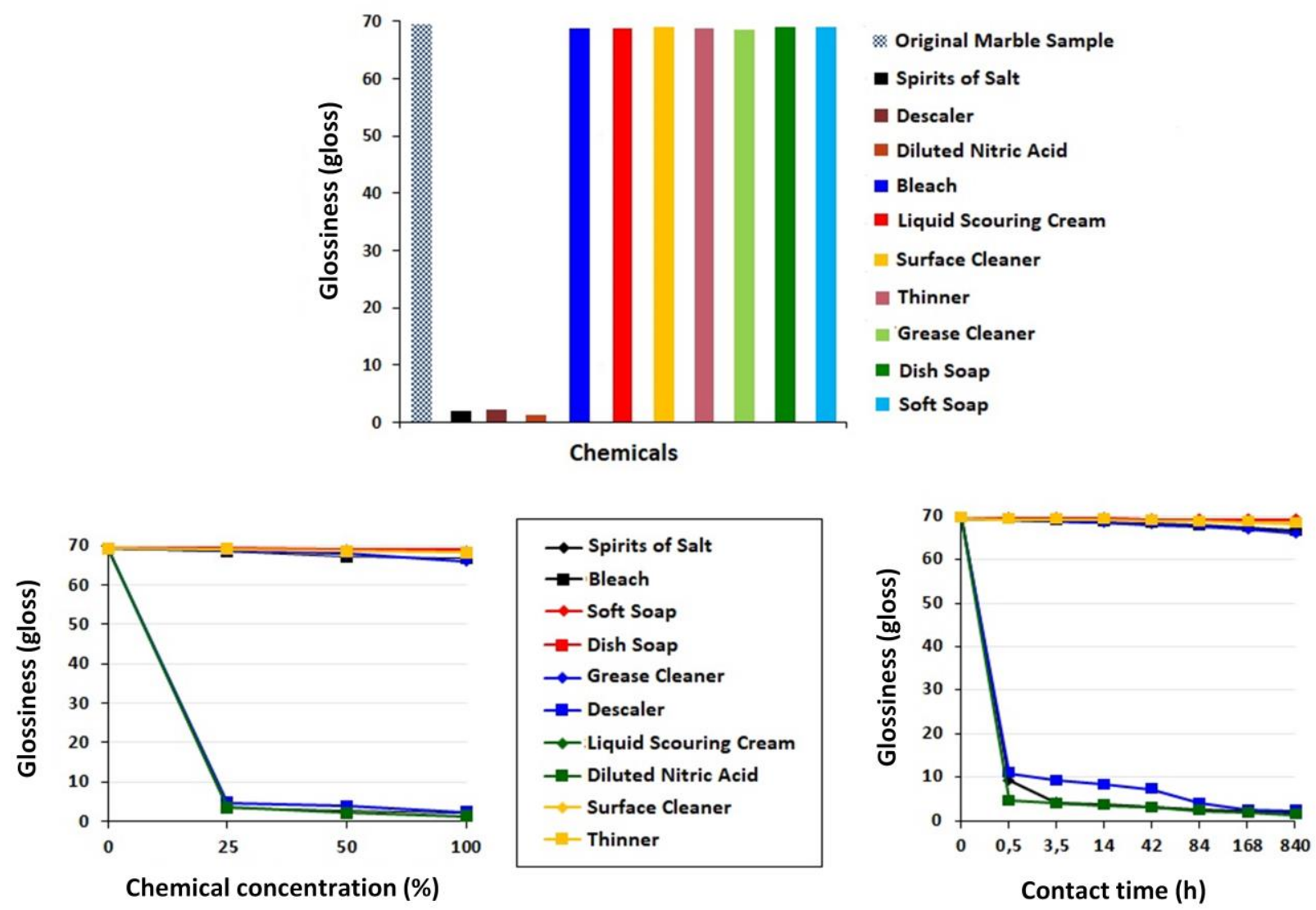

Figure 6. Effects of surface cleaning chemicals on the glossiness of the marble surface.

\subsubsection{The change of color}

Figures 7-8 show the color changes of the marble surfaces after contact of surface cleaning chemicals depending on the concentration, chemical type and contact time. Acidic chemicals were found to increase surface whiteness slightly. While the average surface whiteness $\left(L^{*}\right)$ of the marble sample was $72,31 \%$ before application, it was measured as $74,46 \%, 73,75 \%$, and $73,28 \%$ after the application of nitric acid, spirits of salt, and descaler, respectively. This can be explained by the formation of white colored $\mathrm{CaCl}$ and $\mathrm{Ca}\left(\mathrm{NO}_{3}\right)_{2}$ salts as a result of the reaction of calcite minerals with hydrochloric acid and nitric acid. Other cleaning chemicals which are neutral and alkaline (especially those of alkaline) reduced the whiteness slightly.
As can be seen in Figure 8, nitric acid, spirits of salt, and descaler were the chemicals that reduce/change the surface redness value of marble samples the most. While the surface redness value of the marble sample before application was 4,82 before the application, it decreased to $3,53,3,11$ and 2,08 values after the application of acidic chemicals (nitric acid, spirits of salt and descaler), respectively. When the redness value approaches to zero, it shows that the surface is whitened. Although alkaline chemicals did not show a decrease in the redness of marble surface as well as acidic chemicals, there was a slight decrease. On the other hand, chemicals with a neutral character caused a slight increase in the sample surface redness value. 

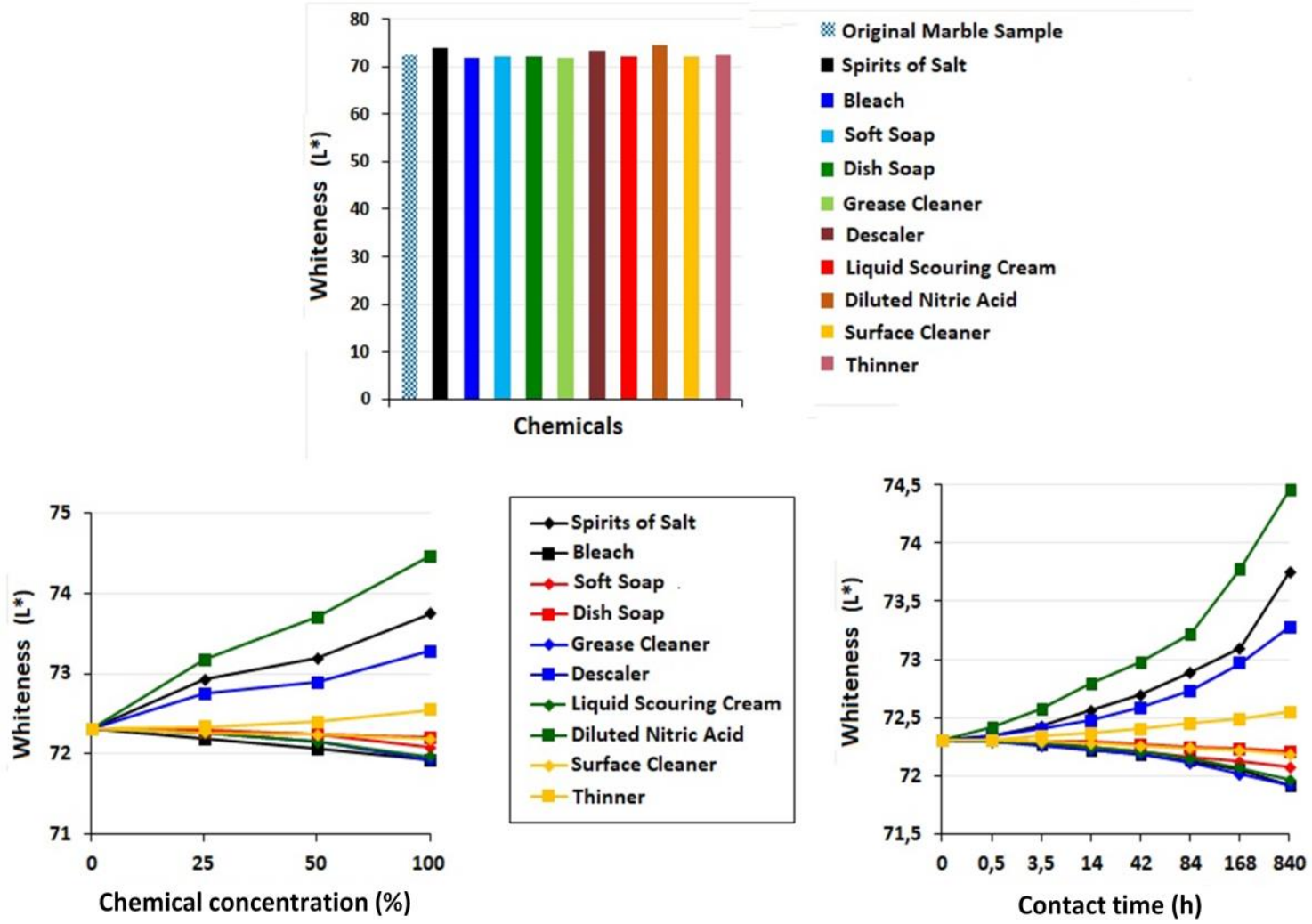

Figure 7. Effects of surface cleaning chemicals on the color of the marble surface (whiteness).

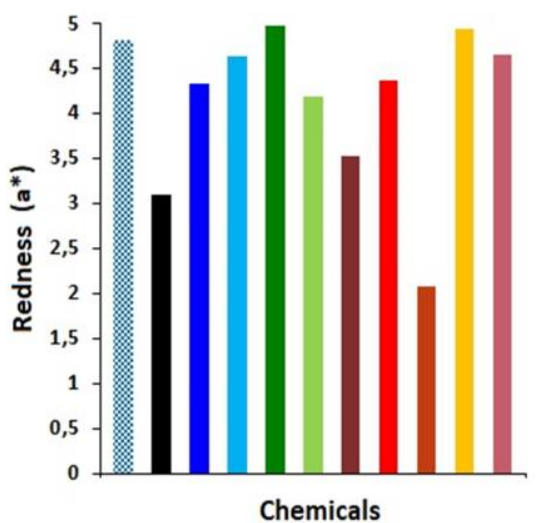

— Original Marble Sample
- Spirits of Salt
- Bleach
- Soft Soap
- Dish Soap
- Grease Cleaner
- Descaler
- Liquid Scouring Cleaner
- Diluted Nitric Acid
- Surface Cleaner
- Thinner

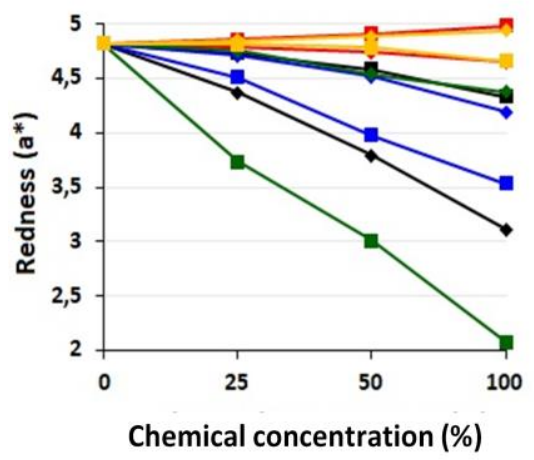

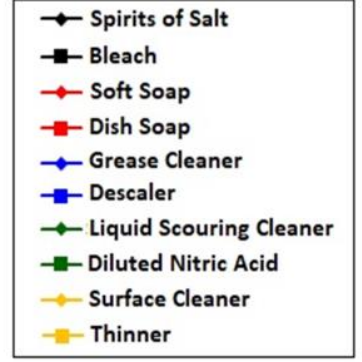

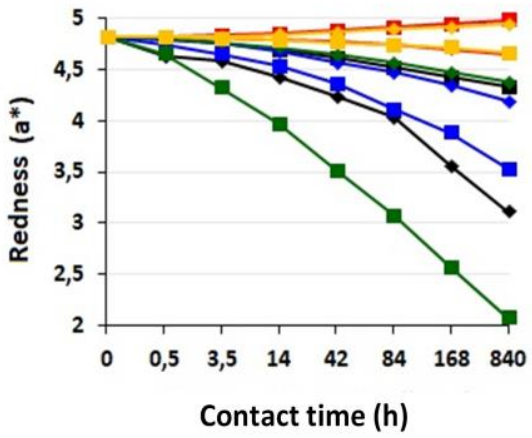

Figure 8. Effects of surface cleaning chemicals on the color of the marble surface (redness). 


\section{Conclusion}

In this study, effects of various cleaning chemicals on polished marble surface characteristics and mass loss of marble were investigated depending on contact time, chemical type, and chemical concentration. The effects of cleaning chemicals were increased at high concentrations and long contact times, and marble surface deformations increased accordingly. It has been observed that the reaction between the calcite minerals and acidic chemical significantly affected the surface of the marble surfaces, while higher resistance was seen against neutral and alkaline chemicals. As a result, in order to maintain the aesthetic appearance of natural stones as long as possible, neutral/alkaline chemicals (soft soap, bleach and cream detergents) and chemicals diluted with water should be used in the cleaning of natural stones instead of acidic chemicals (nitric acid, spirits of salt and lime remover).

\section{Acknowledgments}

This study was financially supported by Afyon Kocatepe University, Scientific Research Project (BAP), Project No: 14.FEN.BIL.32.

\section{References}

Ceylan, H.R., 2016. Çeşitli temizlik kimyasallarının mermer ve granitin yüzey özelliklerine etkisi, Yüksek Lisans Tezi, Afyon Kocatepe Üniversitesi Fen Bilimleri Enstitüsü, Afyonkarahisar, 201.

Gökaltun, E., 2004. Atmosferik kirleticiler ile temizlik amaçlı kimyasalların doğal taş yapı malzemeleri üzerindeki etkileri. Anadolu Üniversitesi Bilimsel Araştırma Fonu Projesi, Proje No: 20232.

Gökaltun, E., 2005. Atmosferik etkilerle mermer ve granit kaplama malzemelerinde meydana gelen parlaklık kayıplarının ölçümü üzerine bir yöntem. Inşaat Dünyası Dergisi, 5, 78-80.

Gündüz, L., Şentürk, A. ve Tosun, Y.ì., 1996. Asitlerin mermer karakteristiğine etkisi. Türkiyede Mermer Dergisi, 45, 9-16.

Moropoulou, A., Delegou, E., Karaviti, E. and Vlahakis V, 2006, Assessment of atmospheric pollution impact on the microstructure of marble surfaces-Measuring, Monitoring and Modeling Concrete Properties, Konsta-Gdoutos M.S. (eds), Springer, 695-701.

Spiker, E.C., Hosker, R.P., Weintraub, V.C. and Sherwood, S.I., 1995. Laboratory study of $\mathrm{SO}_{2}$ dry deposition on limestone and marble: Effects of humidity and surface variables. Kluwer Academic Publishers, 85(4), 2679-2685.

Schuster, P.F., Reddy, M.M., Sherwood, S.I., 1994. Effects of acid rain and sulfur dioxide on marble dissolution. Materials Performance, 33(1), 7680.

Tecer, L., Cerit, O., 2002. The effects of air pollution on carbonate stone monuments in urban areas (Sivas, Turkey). Fresenius Environmental Bulletin, 11(8), 505-509.

TS 6956, 2004. Geometrik mamul özellikleri (GMÖ), yüzey yapısı, profil metodu, terimler ve yüzey yapısı parametreleri. Türk Standartları Enstitüsü (TSE), Ankara, 24.

Vella, A.J., Camilleri, A. and Tabone Adami, J.P., 1996. Limestone surfaces in built-up environment as indicators of atmospheric pollution. Environmental Geochemistry and Health Journal, 18(4), 165-70. 